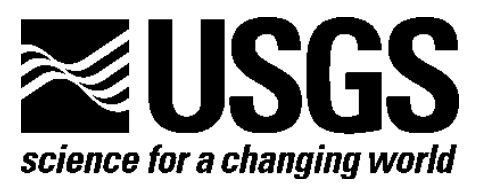

\title{
Radon-222 Content of Natural Gas Samples from Upper and Middle Devonian Sandstone and Shale Reservoirs in Pennsylvania: Preliminary Data
}

By E.L. Rowan and T.F. Kraemer

Open-File Report Series 2012-1159

U.S. Department of the Interior

U.S. Geological Survey 


\section{U.S. Department of the Interior \\ KEN SALAZAR, Secretary}

\section{U.S. Geological Survey \\ Marcia K. McNutt, Director}

U.S. Geological Survey, Reston, Virginia: 2012

For more information on the USGS-the Federal source for science about the Earth, its natural and living resources, natural hazards, and the environment-visit http://www.usgs.gov or call 1-888-ASK-USGS

For an overview of USGS information products, including maps, imagery, and publications, visit $h$ ttp://www.usgs.gov/pubprod

To order this and other USGS information products, visit http://store.usgs.gov

Suggested citation:

Rowan, E.L., and Kraemer, T.F., 2012, Radon-222 Content of natural gas samples from Upper and Middle Devonian sandstone and shale reservoirs in Pennsylvania: Preliminary data: U.S. Geological Survey Open-File Report 2012-1159, 6 p., http://pubs.usgs.gov/of/ 2012/1159. (Available only online.)

Any use of trade, product, or firm names is for descriptive purposes only and does not imply endorsement by the U.S. Government.

Although this report is in the public domain, permission must be secured from the individual copyright owners to reproduce any copyrighted material contained within this report. 


\section{Contents}

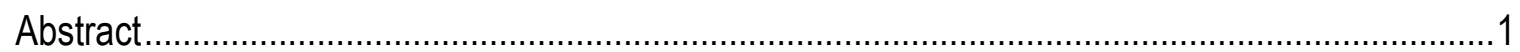

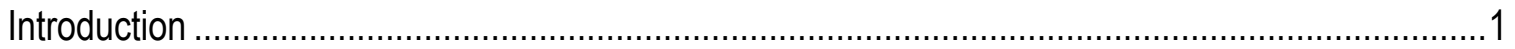

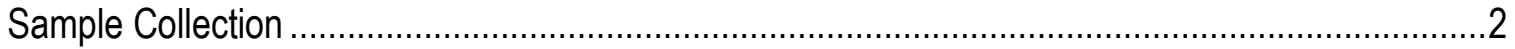

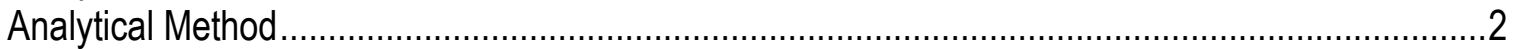

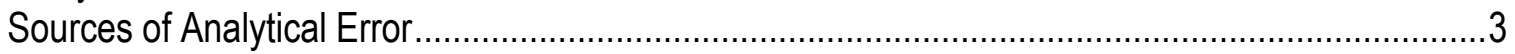

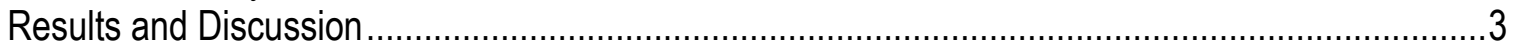

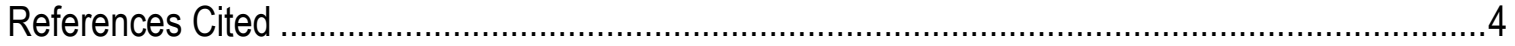

\section{Table}

1 Radon activity of natural gas samples at STP (standard temperature and pressure) from 11 wells in Pennsylvania, reservoir name and age, lithology, and approximate reservoir

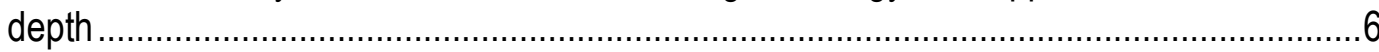




\title{
Radon-222 Content of Natural Gas Samples from Upper and Middle Devonian Sandstone and Shale Reservoirs in Pennsylvania: Preliminary Data
}

\author{
By E.L. Rowan and T.F. Kraemer
}

\begin{abstract}
Samples of natural gas were collected as part of a study of formation water chemistry in oil and gas reservoirs in the Appalachian Basin. Nineteen samples (plus two duplicates) were collected from 11 wells producing gas from Upper Devonian sandstones and the Middle Devonian Marcellus Shale in Pennsylvania. The samples were collected from valves located between the wellhead and the gas-water separator. Analyses of the radon content of the gas indicated ${ }^{222} \mathrm{Rn}$ (radon-222) activities ranging from 1 to 79 picocuries per liter $(\mathrm{pCi} / \mathrm{L})$ with an overall median of $37 \mathrm{pCi} / \mathrm{L}$. The radon activities of the Upper Devonian sandstone samples overlap to a large degree with the activities of the Marcellus Shale samples.
\end{abstract}

\section{Introduction}

The U.S. Geological Survey (USGS) is conducting ongoing research to characterize the geochemistry of produced waters from the major oil- and natural-gas producing reservoirs in the Appalachian Basin. In the course of this work, 19 gas samples, plus two duplicates, were collected from wells producing from sandstone reservoirs in the Upper Devonian Bradford and Elk Groups and from the Middle Devonian Marcellus Shale.

Radon is a radioactive noble gas that occurs in the uranium and thorium decay series. It is chemically inert and is preferentially partitioned into a gas phase relative to water (Kraemer, 1986). The only isotope of radon with a significantly long half-life is ${ }^{222} \mathrm{Rn}\left(\mathrm{t}_{1 / 2}=3.8\right.$ days $\left.{ }^{1}\right)$, making it the most likely radon source for exposure of the general public. ${ }^{222} \mathrm{Rn}$ occurs in the ${ }^{238} \mathrm{U}$ decay chain and forms directly from the alpha decay of ${ }^{226} \mathrm{Ra}$, a radionuclide that is commonly present in the formation waters of sedimentary basins including the Appalachian Basin (Kraemer and Reid, 1984; Fisher, 1998; Rowan and others, 2011).

A recent report by Resnikoff (2012) has led to increased interest in possible human exposure to radon as a component of natural gas in household settings. The report, however, relied on theoretical calculations utilizing limited data from geologic analogs. A decision was made to release our small and preliminary dataset because, to the authors'

\footnotetext{
${ }^{1}$ National Nuclear Data Center (http://www.nndc.bnl.gov/chart).
} 
knowledge, measurements of radon in natural gas at the wellhead have not previously been published for the Appalachian Basin.

\section{Sample Collection}

Samples were taken from producing gas wells, from valves located between the wellhead and the gas-water separator, at gas line pressure, which was typically between 50 and 500 pounds per square inch (psi). Gas samples were taken only from points past which gas had flowed continuously for at least 24 hours, to avoid possible stagnant accumulations of gas and thus the possibility of underestimating ${ }^{222} \mathrm{Rn}$ content due to its rapid decay. The samples were collected in stainless steel cylinders of 200- or 500milliliter volume. Care was taken to fill and then release gas from the cylinders several times before collecting the sample to remove any air or traces of the previous sample. Gas was allowed into or out of the cylinder only at low flow rates to avoid (1) entrainment of water into the cylinder and (2) precipitation of hydrocarbon liquids or water as a result of adiabatic cooling. The line pressure was noted, and collection time was recorded to allow calculation of the radon decay in the elapsed interval between sample collection and analysis.

\section{Analytical Method}

The samples were analyzed for ${ }^{222} \mathrm{Rn}$ in the laboratory using a Pylon AB-5 radon field-portable scintillation measurement system consisting of Lucas cells (Lucas, 1957), a photomultiplier tube, and a radon extraction and transfer unit (not used in this procedure). Use of the Lucas cell for radon measurement is an established approach in field and laboratory settings (Mathieu and others, 1988; Hamlat and others, 2003; Papastefanou, 2007; Smith and others, 2008).

The Lucas cell was evacuated and then attached to a sample cylinder with in-line valves, expansion tubing, and a pressure gage. The Lucas cell was filled with sample by opening the cylinder to the evacuated expansion tubing and then closing the cylinder valve and opening the valve to the Lucas cell. After the pressure stabilized, the process was repeated if necessary until the cell was filled with natural gas to approximately atmospheric pressure. The final pressure was recorded and the Lucas cell placed on the AB-5 photomultiplier tube to count total alpha activity. The counting interval was 90 minutes and was repeated as time permitted. Radon activities were calculated from the counting data after correcting for the efficiency of the Lucas cell, the cell volume, the recorded pressures, and the time interval between sample collection and counting.

To test whether the radon counting efficiencies were the same for the natural gas samples as in air, we recorded counts from a radon source, first in air, then in methane to approximate the composition of the natural gas. The radon source consisted of a ${ }^{226} \mathrm{Ra}$ bearing solution obtained from the National Institute of Standards and Technology (NIST) in a gas-permeable plastic tube that was placed in a flask and sealed. An evacuated Lucas cell was attached to the flask, filled either with air or with methane, and radon counts were recorded. Two such tests were conducted in air and two in methane. The ratio of radon counts recorded in methane versus counts recorded in air was 0.68 . Accordingly, the resulting radon activities of the samples were divided by 0.68 , 
increasing the values to correct for the fact that the measurements were made in natural gas (predominantly methane) with cell efficiencies calibrated for air.

\section{Sources of Analytical Error}

The cumulative error from sources inherent in the measurements is estimated to be \pm 25 percent for samples with radon activities $>10 \mathrm{pCi} / \mathrm{L}$, and possibly greater in samples with lower radon activities. The main sources of potential analytical error are summarized below.

1. Imperfect evacuation of the Lucas cell before filling with sample gas (about 10 percent systematic error). The pump used was capable of reaching about -27 inches of mercury representing approximately 90 percent evacuation.

2. Use of an uncalibrated electronic pressure gage to measure final sample pressure. The pressure gage was adjusted to a zero reading on the digital display if necessary before each filling procedure (systematic error).

3. Variation in Lucas cell volume and efficiency relative to values reported by the manufacturer resulting in random errors of approximately \pm 2 percent for volume and \pm 3 percent for efficiency.

4. Use of an empirically derived ratio between count rates in air versus methane, as described above (systematic error).

5. Measurement of low radon activities relative to cell backgrounds. The measurement error increases as the difference between sample and background count rates decreases. Many of the natural gas samples had intrinsically low radon activities, which decreased further due to radioactive decay in the interval between sample collection and analysis (random error).

6. Cylinder blanks were not measured and therefore could not be used to correct the final radon activities. Possible radium contamination in the cylinder could represent an additional and ongoing source of radon generated by ${ }^{226}$ Ra decay. However, most of the samples analyzed approached near-zero activity after 30 days, consistent with unsupported ${ }^{222} \mathrm{Rn}$ whose half-life is 3.8 days. The error associated with the possible presence of radium is therefore assumed to be negligible.

\section{Results and Discussion}

Table 1 lists the ${ }^{222} \mathrm{Rn}$ activities of the gas samples at standard temperature and pressure $\left(25^{\circ} \mathrm{C}\right.$ and 1 atmosphere) at the time of sample collection; that is, they have been corrected to account for radon decay in the time elapsed between sample collection and laboratory measurement. The reservoirs sampled include sandstones within the Upper Devonian Bradford and Elk Groups and the Middle Devonian Marcellus Shale. Reservoir lithology and approximate depth are also listed for each well. The ${ }^{222} \mathrm{Rn}$ activities of the samples range from 1 to 79 picocuries per liter (pCi/L); an overall median of $37 \mathrm{pCi} / \mathrm{L}$ was calculated using the average values for two sets of duplicate samples.

The ${ }^{222} \mathrm{Rn}$ activities of samples from the Upper Devonian sandstones overlap those of the Marcellus Shale to a large degree. The Upper Devonian sample activities 
range from 7 to $65 \mathrm{pCi} / \mathrm{L}$ with a median of $42 \mathrm{pCi} / \mathrm{L}$, while the Marcellus sample activities range from 1 to $79 \mathrm{pCi} / \mathrm{L}$ with a median of $32 \mathrm{pCi} / \mathrm{L}$. Although no meaningful difference in the ${ }^{222} \mathrm{Rn}$ activities for the two groups of samples is apparent from the data presented here, the total number of samples is too small to reliably characterize the reservoirs or to yield statistically valid results.

The activity of radon in natural gas in the reservoir is ultimately determined by the abundance of its source, ${ }^{226} \mathrm{Ra}$, whose decay to ${ }^{222} \mathrm{Rn}$ is independent of pressure. As radon forms, it preferentially enters a gas phase (if present) and establishes a concentration dependent upon its rate of supply from ${ }^{226} \mathrm{Ra}$ in the reservoir and the rate of ${ }^{222} \mathrm{Rn}$ decay within the gas (Kraemer, 1986). Other factors being equal, including the ${ }^{226} \mathrm{Ra}$ content of the aqueous and solid phases in the reservoir, lower radon activities would be expected in gas originating from a high pressure reservoir than a low pressure reservoir due to the greater relative expansion of the gas from the higher pressured reservoir to surface conditions.

When interpreting the significance of the radon activities, the 3.8-day half-life should be taken into account. Based on the definition of a half-life, radon activity decays to $1 /\left(2^{\mathrm{n}}\right)$ over $\mathrm{n}$ half-lives. For example, in 2 half-lives (7.6 days) from the time the gas leaves the reservoir, the radon activity would decay to $1 /\left(2^{2}\right)$, or 25 percent of its original activity. The highest radon activity reported here, approximately $79 \mathrm{pCi} / \mathrm{L}$, would decay to $19.8 \mathrm{pCi} / \mathrm{L}$ over this time period. Additionally, in a household setting, radon that originated from natural gas would be diluted with air, although those calculations are outside the scope of this report. For comparison, the U.S. Environmental Protection Agency (EPA) threshold for remediation of radon in indoor air is $4 \mathrm{pCi} / \mathrm{L}^{2}$.

The key to better understanding radon, its sources, and behavior in hydrocarbon reservoirs lies with the collection and interpretation of additional data. Examples of the types of data that might be collected include (1) time-series measurements to document temporal variability in radon activity with changing water and gas production rates and changing reservoir pressures, (2) measurements on samples from reservoirs in a single formation (and lithology) but from a range of depths and pressures to confirm the role of pressure and volume expansion in reducing the radon activity at surface conditions, and (3) analyses of radon in gas samples more broadly across the Appalachian Basin to define regional variations with source rock thermal maturity, gas composition (for example, wetness), and other factors.

\section{References Cited}

Fisher, R.S., 1998, Geologic and geochemical controls on naturally occurring radioactive materials (NORM) in produced water from oil, gas, and geothermal operations:

Environmental Geosciences, v. 5, p. 139-150.

Hamlat, M.S., Kadi, H., Djeffal, S., and Brahimi, H., 2003, Radon concentrations in Algerian oil and gas industry: Applied Radiation and Isotopes, v. 58, p. 125-130.

Kraemer, T.F., 1986, Radon in unconventional natural gas from Gulf Coast geopressuredgeothermal reservoirs: Environmental Science and Technology, v. 20, p. 939-942.

Kraemer, T.F., and Reid, D. F., 1984, The occurrence and behavior of radium in saline formation water of the U.S. Gulf Coast region: Isotope Geoscience, v. 2, p. 153-174.

${ }^{2}$ http://www.epa.gov/radon/aboutus.html. 
Lucas, H. F., 1957, Improved low-level alpha-scintillation counter for radon: Review of Scientific Instruments, v. 28, no. 9, p. 680-683.

Mathieu, G., Biscayne, P., Lupton, R., and Hammond, D. E., 1988, System for measurement of ${ }^{222} \mathrm{Rn}$ at low level in natural waters: Health Physics, v. 55, p. 989-992. Papastefanou, C., 2007, Measuring radon in soil gas and groundwaters: a review: Annals of Geophysics, v. 50, p. 569-578.

Resnikoff, M., 2012, Radon in natural gas from Marcellus Shale: NEOGAP, Network for Oil \& Gas Accountability and Protection, 14 p., available at http://www.neogap.org/neogap/2012/01/18/radon-in-natural-gas-report-resnikoff_1-10$12 /$

Rowan, E.L., Engle, M.A., Kirby, C.S., and Kraemer, T.F., 2011, Radium content of oiland gas-field produced waters in the northern Appalachian Basin (USA): Summary and discussion of data: U.S. Geological Survey Scientific Investigations Report 2011-5135, 31p.

Smith, C. G., Cable, J. E., Martin, J., and Moutusi, R., 2008, Evaluating the source and seasonality of submarine groundwater discharge using a radon-222 pore water transport model: Earth and Planetary Science Letters, v. 273, p. 312-322. 
Table 1. Radon activity of natural gas samples at STP (standard temperature and pressure) from 11 wells in Pennsylvania, reservoir name and age, lithology, and approximate reservoir depth. [In the Sample ID column, letters indicate individual wells, and numbers indicate that multiple samples were collected from a given well. Two duplicate samples were collected at well A. pCi/L, picocuries per liter; ft, feet]

\begin{tabular}{lcllc}
\hline \multicolumn{1}{c}{ Sample ID } & $\begin{array}{c}\text { 222Rn Activity } \\
\text { (pCi/L) }\end{array}$ & \multicolumn{1}{c}{ Reservoir Name and Age } & Lithology & $\begin{array}{c}\text { Approximate } \\
\text { Reservoir } \\
\text { Depth (ft) }\end{array}$ \\
\hline A-1 & 35 & Marcellus Shale, Middle Devonian & Black shale & 8,000 \\
A-2 & 40 & Marcellus Shale, Middle Devonian & Black shale & 8,000 \\
A-2, duplicate & 45 & Marcellus Shale, Middle Devonian & Black shale & 8,000 \\
A-3 & 79 & Marcellus Shale, Middle Devonian & Black shale & 8,000 \\
A-3, duplicate & 79 & Marcellus Shale, Middle Devonian & Black shale & 8,000 \\
A-4 & 76 & Marcellus Shale, Middle Devonian & Black shale & 8,000 \\
A-5 & 1 & Marcellus Shale, Middle Devonian & Black shale & 8,000 \\
A-6 & 3 & Marcellus Shale, Middle Devonian & Black shale & 8,000 \\
B-1 & 38 & Marcellus Shale, Middle Devonian & Black shale & 8,000 \\
B-2 & 1 & Marcellus Shale, Middle Devonian & Black shale & 8,000 \\
B-3 & 4 & Marcellus Shale, Middle Devonian & Black shale & 8,000 \\
C & 30 & Marcellus Shale, Middle Devonian & Black shale & 8,000 \\
D & 65 & Bradford and Elk Groups, Upper Devonian & Sandstone & 4,000 \\
E & 46 & Bradford and Elk Groups, Upper Devonian & Sandstone & 4,000 \\
F & 42 & Bradford and Elk Groups, Upper Devonian & Sandstone & 4,000 \\
G-1 & 21 & Bradford and Elk Groups, Upper Devonian & Sandstone & 4,000 \\
G-2 & 7 & Bradford and Elk Groups, Upper Devonian & Sandstone & 4,000 \\
H & 37 & Bradford and Elk Groups, Upper Devonian & Sandstone & 4,000 \\
I & 50 & Bradford and Elk Groups, Upper Devonian & Sandstone & 4,000 \\
J & 49 & Bradford and Elk Groups, Upper Devonian & Sandstone & 4,000 \\
K & & Bradford and Elk Groups, Upper Devonian & Sandstone & 6,000 \\
\hline
\end{tabular}

